\title{
Etnomatematika pada Pakaian Adat Lampung
}

\author{
Binti Anisaul Khasanah, Nida Nuria, Liana, Iswahyudi \\ 1234 Universitas Muhammadiyah Pringsewu Lampung \\ * Binti Anisaul Khasanah, e-mail: bintianisaul@umpri.ac.id
}

\begin{abstract}
Indonesia memiliki budaya yang sangat banyak dan beragam. Namun kenyataannya kurang adanya kesadaran masyarakat untuk melindungi dan melestarikannya. Etnomatematika memiliki peran penting dalam upaya mengenalkan budaya kepada generasi muda sekaligus mempelajari konsep matematika. Tujuan dari penelitian ini adalah untuk mengeksplorasi konsep matematika pada pakaian adat Lampung. Metode yang digunakan dalam penelitian ini adalah metode penelitian kualitatif melalui studi literatur. Berdasarkan hasil kajian dan eksplorasi terhadap konsep matematika diperoleh bahwa pakaian adat Lampung mengandung konsep matematika antara lain bentuk geometri, konsep bilangan, sudut dan transformasi geometri. Dengan demikian, diharapkan hasil penelitian ini dapat digunakan sebagai bahan rujukan pada materi matematika sekolah.
\end{abstract}

Keywords: Etnomatematika, Konsep Matematika, Geometri, Bilangan, Sudut.

\section{PENDAHULUAN}

Di tengah perkembangan teknologi pendidikan, kurikulum pendidikan menuntut keterlibatan budaya dalam pembelajaran disekolah (Sulfemi, 2019). Hal ini bertujuan agar peserta didik dapat menjadi generasi yang berkarakter dan mampu menjaga serta melestarikan budaya sebagai landasan karakter bangsa. Nilai budaya penting untuk ditanamkan pada setiap individu, agar mampu memahami, memaknai, dan menghargai serta menyadari pentingnya nilai budaya dalam menjalankan setiap kehidupan. Indonesia memiliki budaya yang sangat banyak dan beragam. Namun kenyataannya kurang adanya kesadaran masyarakat untuk melindungi dan melestarikannya. Peran masyarakat dan pemerintah termasuk dalam hal ini peran pendidikan sangatlah penting, karena dunia pendidikan sebagai fasilitator guna memperkenalkan budayabudaya indonesia kepada anak-anak (generasi) muda Indonesia.

Sardjiyo Paulina Pannen (Wahyuni \& Aji, 2013) mengatakan bahwa pembelajaran berbasis budaya merupakan suatu model pendekatan pembelajaran yang lebih mengutamakan aktivitas siswa dengan berbagai ragam latar belakang budaya yang dimiliki, diintegrasikan dalam proses pembelajaran bidang studi tertentu, dan dalam penilaian hasil belajar dapat menggunakan beragam perwujudan penilaian. Pembelajaran berbasis budaya dapat dibedakan menjadi tiga macam, yaitu belajar tentang budaya, belajar dengan budaya, dan belajar melalui budaya. Ada empat hal yang harus diperhatikan dalam pembelajaran berbasis budaya, yaitu substansi dan kompetensi bidang ilmu/bidang studi, kebermaknaan dan proses pembelajaran, penilaian hasil belajar, serta peran budaya.Pembelajaran berbasis budaya lebih menekankan tercapainya pemahaman yang terpadu(integrated understanding) dari pada sekedar pemahaman mendalam (inert understanding). 
Menurut (Hartoyo, 2012) matematika yang timbul dan berkembang dalam masyarakat dan sesuai dengan kebudayaan setempat, merupakan proses pembelajaran dan metode pengajaran. Pakaian adat Lampung adalah salah satu peninggalan budaya yang khas dan memiliki nilai seni yang tinggi. Pakaian adat Lampung memiliki perbedaan antara pakaian adat Lampung pepadun dan pakaian adat Lampung saibatin, perbedaannya di sebuah siger didalam adat Lampung pepadun memiliki 9 pucuk atau lekukan dan laki-laki memakai kopiah emas.sedangkan dalam adat Lampung saibatin memiliki 7 pucuk atau lekukan. Dan memiliki perbedaan warna pada pakaiannya, pada pakaian suku pepadun didominasi warna putih sedangkan pakaian suku saibatin didominasi dengan warna merah.

Budaya Lampung jika diintegrasikan dalam pembelajaran matematika akan berdampak sangat baik bagi siswa. Siswa akan lebih mengerti budaya yang ada diindonesia. (Musafiri, 2016) menyatakan intergrasi kearifan nilai nilai lokal dapat berdampak pada sebuah penguatan karakter siswa. Selain itu jika siswa memahami lebih mendalam tentang budaya Lampung maka siswa akan lebih mengerti dan menyadari pentingnya sebuah nilai-nilai luhur dari budaya yang ada di Lampung. (Wahyuni \& Aji, 2013) menyatakan bahwa sesuatu yang dapat menggabuangkan antara budaya dan matematika adalah etnomatematika. Etnomatematika adalah matematika dalam lingkup kebudayaan etnomatematika terdiri dari dua kata yaitu etno yang berarti budaya atau etnis dan matematika. Hal ini berarti etnomatematika adalah matematika dalam budaya. Istilah etnomatematika di perkenalkan pada tahun 1977 oleh D'Ambosio adalah sorang matematikawan yang berasal dari brazil.

Ada beberapa hasil penelitian yang mengeksplorasi etnomatematika pada budaya Lampung antara lain: eksplorasi konsep matematika pada permainan tradisional Provinsi Lampung (Merliza, 2021), Etnomatematika Pada Kain Tapis Lampung Motif Pucuk Rebung (Avelia et al., 2020), dan Etnomatematika pada Kain Tapis dan Rumah Adat Lampung (Loviana et al., 2020). Dikarenakan pentingnya pengenalan budaya Lampung melalui studi etnomatematika maka peneliti tertarik untuk melakukan eksplorasi etnomatematika pada pakaian adat Lampung. Pada penelitian ini peneliti melakukan eksplorasi konsep matematika yang ada pada setiap unsur pakaian adat Lampung.

\section{METODE PENELITIAN}

Metode yang digunakan dalam penelitian ini adalah metode penelitian kualitatif. Peneliti menggunakan metode penelitian kualitatif dikarenakan terdapat banyak sumber sekunder (seperti: buku, e-book, artikel ilmiah, web, dan lain sebagainya) yang peneliti gunakan sebagai sumber data terkait pakaian adat Lampung. Informasi mengenai pakaian adat Lampung yang telah dikumpulkan selanjutnya dianalis dan dilakukan eksplorasi terhadap konsep matematika yang terdapat pada pakaian adat Lampung.

\section{HASIL DAN PEMBAHASAN}

Pakaian tradisional Lampung terbagi menjadi 2 macam pakaian yaitu pakaian adat Lampung Saibatin dan pakaian adat Lampung Pepadun. Dari dua macam dan jenis pakaian adat Lampung memiliki sebuah perbedaan pada beberapa corak dan bentuk, namun didalam perbedaan mestinya ada suatu kesamaan dari kedua jenis pakaian adat ini, persamaan itu terletak pada pengunaan kain tradisonal Lampung yang bernama kain tapis.

1. Pakaian Adat Suku Saibatin 
Suku Saibatin adalah kelompok masyarakat Lampung yang bertempat tinggal didaerah Pesisir Lampung Timur, Bandar Lampung, Lampung Selatan, Pesawaran, Tanggamus, dan Lampung Barat. Pakaian pengantin Suku Saibatin memiliki lambang mahkota yang dinamakan Siger. Mahkota saibatin ini memiliki tujuh pucuk atau lekukan yang dinamakan lekuk pitu. Pakaian Suku Saibatin didominasi warna merah.

2. Pakaian Adat Suku Pepadun

Suku adat pepadun ialah kelompok adat besar dalam sebuah masyarakat Lampung, masyarakat pepadun ini mendiami daerah yang ada didataran tinggi atau di daerah pendalaman. Perkembangan suku pepadun ini awalnya disuatu daerah abung way kanan dan pubian. Pakaian adat Lampung pepadun didominasi warna putih dan siger pada pakaian adat Lampung pepadun ini memiliki sembilan lekukan.

Pakaian adat untuk pria Lampung berupa baju lengan panjang yang warna putih. Untuk bagian bawahannya, mereka mengenakan celana berwarna hitam. Di bagian pinggang dililitkan sarung dengan motif tumpal. Sarung khas Lampung ini ditenun dengan menggunakan benang emas. Cara mengenakan kain sarung ini dikenakan di bagian luar celana dengan panjang mencapai lutut. Selain itu pria Lampung juga mengenakan selendang bujur sangkar yang dinamakan Khikat Akhir. Sarung ini dilingkarkan dibagian pundak hingga menutupi bahu.

Adapun asesoris yang terdapat pada pakaian adat Lampung yaitu:

1. Mahkota emas yang melambangkan keagungan adat dan budaya Lampung dinamakan siger. Siger tersebut memiliki 9 ruji, yang melambangkan 9 sungai yang ada di provinsi Lampung.

2. Seraja Bulan, yaitu mahkota kecil dengan 3 ruji. Penggunaannya diletakkan di atas Siger. Seraja Bulan bermakna sebagai pengingat bagi warga Lampung, terutama generasi mudanya, bahwa dulu Lampung memiliki 5 kerajaan. Kelima kerajaan itu adalah Kerajaan Ratu di Belalu, Kerajaan Ratu Darah Putih, Kerajaan Ratu di Punggung, Kerajaan Ratu di Puncak, dan Kerajaan Ratu di Pemanggilan.

3. Subang adalah perhiasan serupa dengan anting. Pemakaiannya digantungkan di ujung daun telinga. Biasanya berbentuk mirip buah kenari dan terbuat dari emas.

4. Perhiasan leher dan dada berupa kalung Buah Jukum, kalung Papanjajar, dan kalung Ringgit.

5. Gelang terdiri dari 4 jenis yaitu gelang Kano, gelang Burung, gelang Bibit, dan gelang Duri.

6. Hiasan pada pinggang berupa Selempang Pinang yang sama seperti pada pakaian pria.

7. Bulu Serti, yaitu ikat pinggang dari kain beludru berwarna merah. Ikat pinggang ini dihiasi kelopak bunga dari logam kuningan.

A. Konsep Matematika pada Pakaian Adat Lampung 


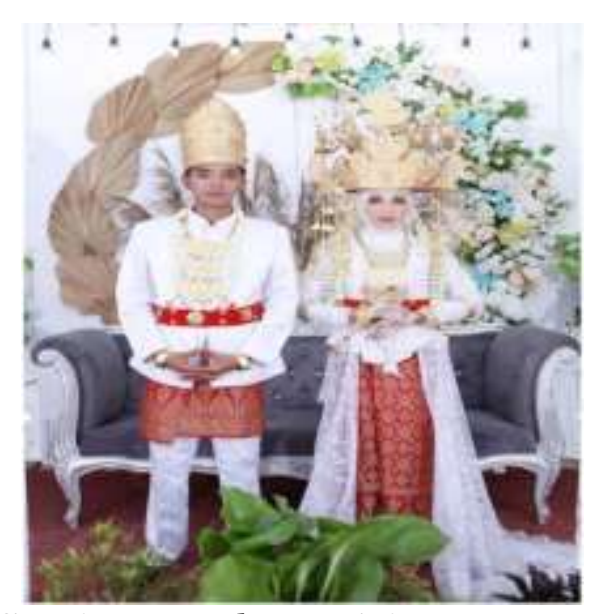

Gambar 1. Pakaian Adat Lampung

\section{Siger}

Siger adalah nama pakaian adat Lampung yang dipakai dikepala (mahkota)yang berwarna emas dalam siger memiliki keistimewaan dikarenakan punya 9 lekukan dan bentuknya meninggi.siger yang memiliki 9 lekukan yaitu siger adat pepadun, sedangkan siger saibatin hanya memiliki 7 lekukan pada siger tersebut. Simbol dari siger pepadun adalah melambangkan keagungan masyarakat adat Lampung yang berjumblah Sembilan yang melambangkan sembilan sungai di Lampung yaitu Way Pengubuan, Way Sekampung, Way Tulang Bawang, Way Menggala, Way Seputih, Way Mesuji, Way Semangka, Way Jepara, dan Way Terusan. Sedangan siger saibatin yang bermakna tujuh adok atau 7 gelar yang ada di adat saibatin.

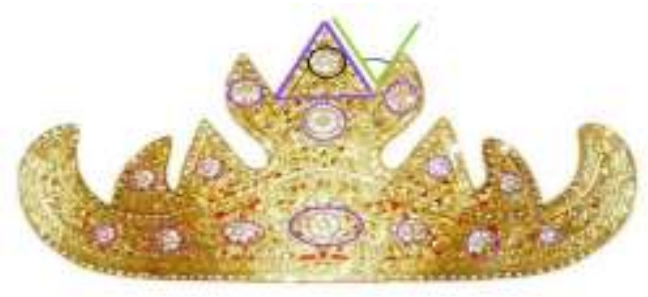

Gambar 2. Siger

Unsur matematika yang ada pada siger terdapat pada lekukan Sembilan, karena pada lekukan Sembilan mempunyai sebuah unsur matematika bangun datar yaitu segitiga dan pada bagian manik-maniknya yang berjumblah 15 memiliki bentuk lingkaran dan di bagian atas siger membentuk sebuah sudut 45 derajat.

2. Kain tapis

a. Kain Tapis Motif rebung

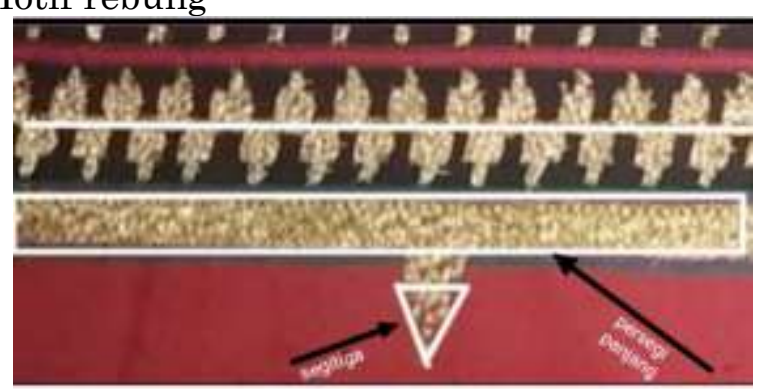

Gambar 3. Kain Tapis Motif rebung 
Motif tapis pada Gambar 3 terdapat sebuah konsep matematika geometri yaitu bangun datar segitiga dan persegi panjang.

b. Kain Tapis Motif Gunung Sayap

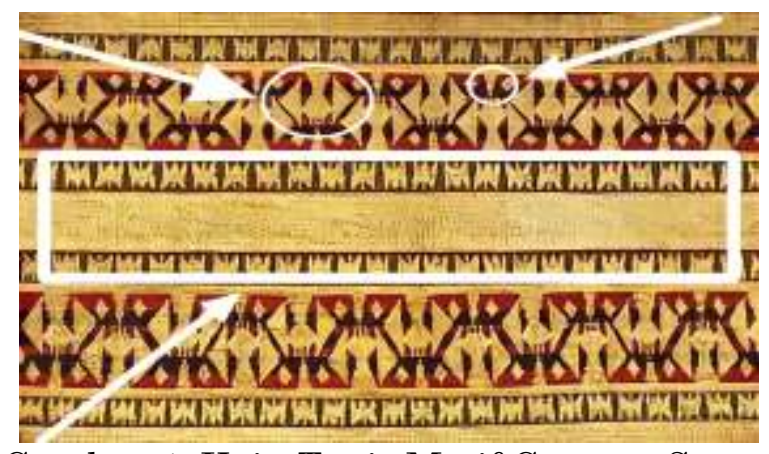

Gambar 4. Kain Tapis Motif Gunung Sayap

Motif kain tapis pada gambar 4 terdapat gambar bangun datar persegi panjang dan segitiga. Gambar 4 juga menunjukkan pencerminan segitiga.

c. Kain Tapis Motif Belah Ketupat

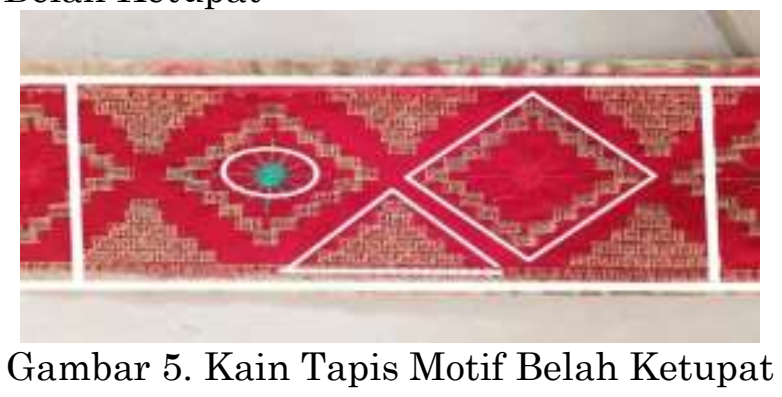

Pada gambar 5 terdapat gambar bangun datar belah ketupat yang di dalamnya diberi gambar lingkaran, segitiga, persegi panjang, dan konsep teransformasi geometri yakni pencerminan.

\section{d. Kain Tapis Motif Pucuk Rebung}

Motif Pucuk Rebung terdiri dari 3 bagian yakni atas, tengah, dan bawah. Bagian atas dan bawah merupakan sulaman benang emas yang bertingkat dan berukuran kecil. Sedangkan bagian tengah adalah sulaman benang emas yang bertingkat, berukuran lebih besar, dan antar tingkatan saling menyambung serta berbalikan secara bergantian. Pada satu kain penuh, motif ini dibuat secara berulang dari atas sampai bawah dan dibatasi oleh satu garis emas yang berukuran lebih lebar. Panjang dari motif ini mengikuti panjang dari kain tenun. Bagian atas, tengah dan bawah motif dan kain Tapis tampak penuh.

Konsep transformasi geometri yang terdapat dalam motif ini adalah refleksi, rotasi, translasi. Konsep-konsepnya dapat diuraikan sebagai berikut:

1) Konsep Rotasi dan Translasi

Rotasi atau perputaran merupakan transformasi geometri berupa pergeseran atau pemindahan semua titik pada bidang geometri sepanjang busur lingkaran yang memiliki titik pusat lingkaran sebagai titik rotasi. Sedangkan Translasi merupakan pergeseran atau pemindahan semua titik pada bidang geometri sejauh dan arah yang sama. Konsep rotasi sekaligus translasi ditunjukan pada gambar 6 berikut: 


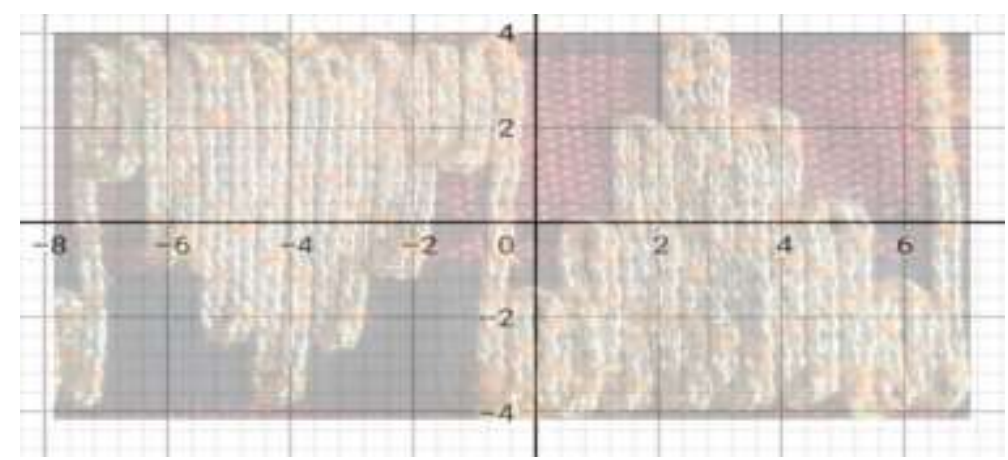

Gambar 6. Rotasi dan Translasi pada Kain Tapis Pucuk Rebung

2) Konsep Refleksi

Refleksi merupakan transformasi geometri berupa pergeseran atau pemindahan semua titik pada bidang geometri kearah sebuah garis atau cermin dengan jarak sama dengan dua kali jarak titik ke cermin.

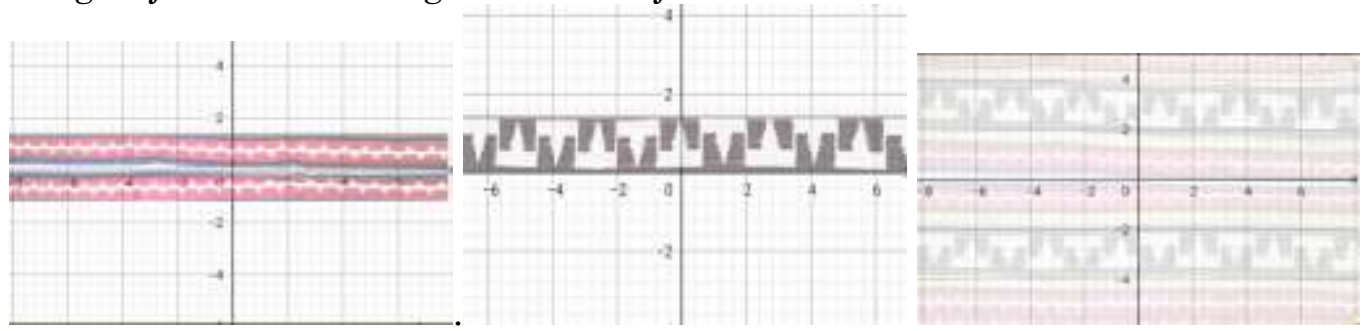

Gambar 7. Konsep Refleksi Kain Tapis Pucuk Rebung

3. Aksesoris pakaian adat Lampung

Aksesoris yang terdapat bada bagian tangan yaitu gelang.Gelang yang di pakai pengantin Lampung pepadun ini antara lain : gelang burung, gelang kano, dan gelang ruwi. Gelang

sebuah burung

Gelang burung mempunyai unsur matematika yaitu lingkaran dan trapesium.

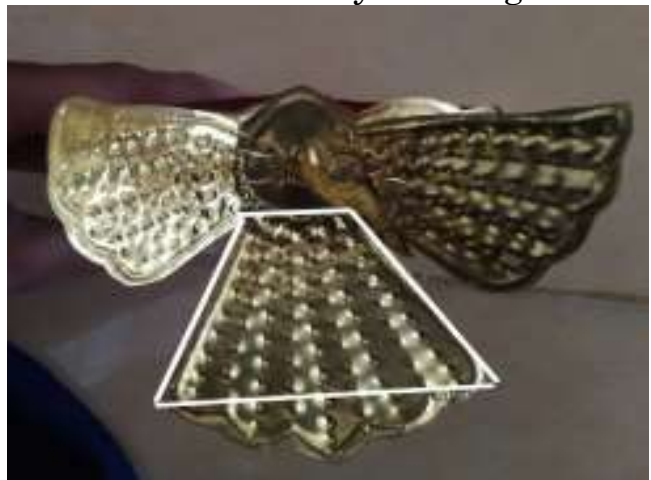

2) Gelang kano

Gambar 8. Gelang Burung

Gelang kano memiliki unsur matematika yaitu lingkaran dan persegi panjang. 


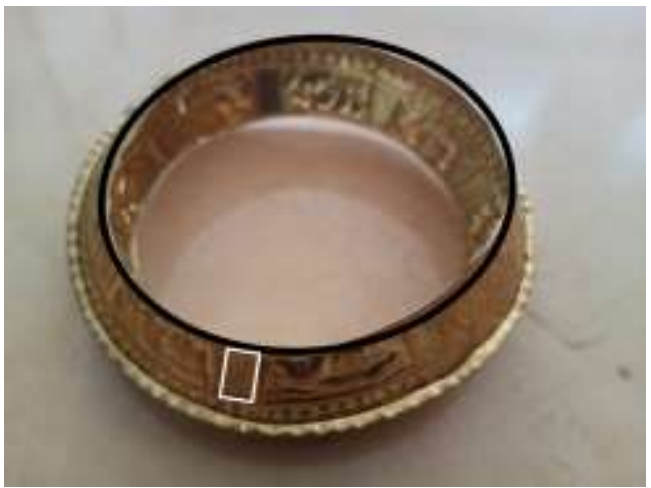

Gambar 9. Gelang Kano

3) Gelang ruwi atau gelang mekah

Gelang ruwi memiliki unsur matematika yaitu limas dan lingkaran.

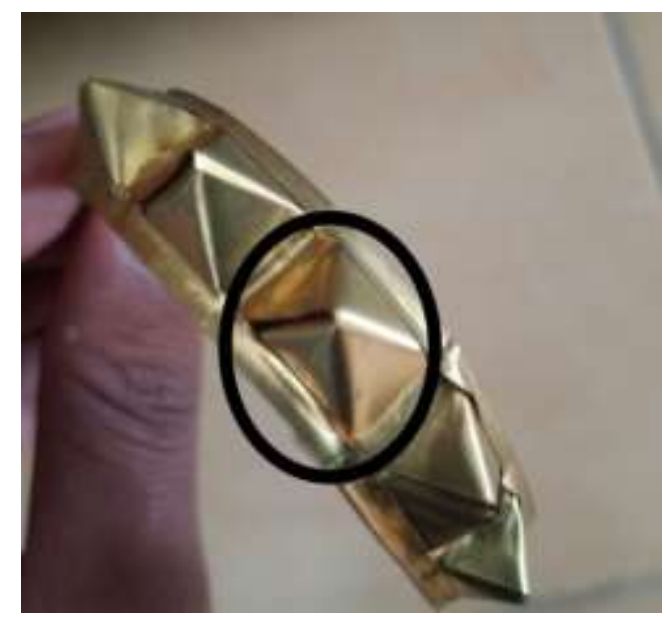

Gambar 10. Gelang Riwi

a. Perhiasan leher dan dada

Perhiasan leher dan dada yang terdapat dalam pakaian adat Lampung diantaranya kalung buah jukum, kalung ringit, dan kalung papan jajar. Kalung papan jajar adalah kalung yang terdiri dari gantungan tiga lempengan siger kecil yang bentunya seperti perahu yang menjadi simbol kehidupan baru bagi para pengantin Lampung. Selanjutnya, kalung ringit adalah kalung yang terdiri dari aksesori Sembilan buah uang ringit, sedangkan kalung buah jukum adalah kalung yang bentuknya menyerupai buah jukum yang dirangkai untuk di jadikan simbolis.

a) Kalung Papan Jajar 


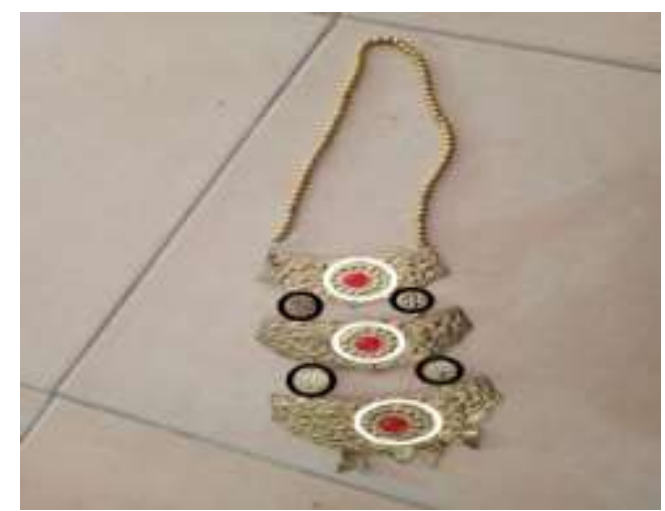

Gambar 11. Kalung Papan Jajar

Pada kalung papan jajar. terdapat konsep matematika yaitu: lingkaran, pada rantai kalung. segitiga, pada pucuk kalung dan pada hiasan yang menggantung di bagian paling bawah kalung. Kalung ini juga memiliki konsep bangun datar trapesium karena bentuk 3 lempengan kalung yang berbentuk seperti kapal. sudut lancip, sudut siku-siku dan sudut tumpul. Pada bagian pucuk atau lancipan kalung ini juga terdapat unsur matematika tentang konsep bilangan karena terdiri dari 3 lempengan dan juga terdiri dari 5 gantungan kecil.

b) Seraja bulan

Seraja bulan merupakan mahkota yang bentuknya lebih kecil dari siger yang bersusun tiga. Seraja bulan dipakai tepat di atas siger.

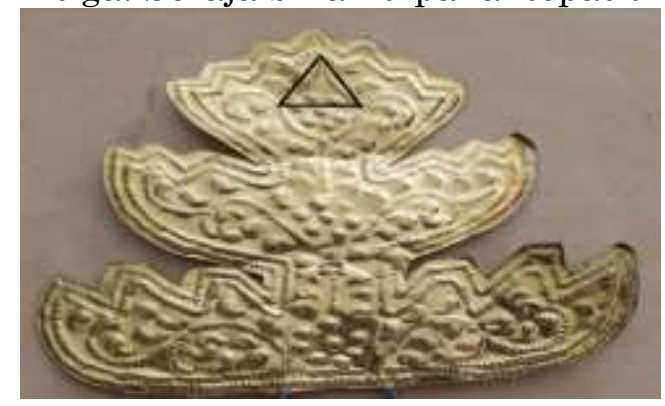

Gambar 12. Seraja Bulan

Konsep matematika yang terdapat pada seraja bulan antara lain: Segitiga yang terdapat pada setiap pucuk seraja bulan dan Bilangan yaitu seraja bulan memiliki tiga susunan.

c) Kembang Cempaka

Kembang cempaka ini di pakai pada bagian kepala di sekitar siger. Biasanya di tancapkan pada pucuk-pucuk siger. Konsep matematika yang terdapat pada kembang cempaka adalah bangun datar lingkaran dan segitiga.

d) Buah manggus

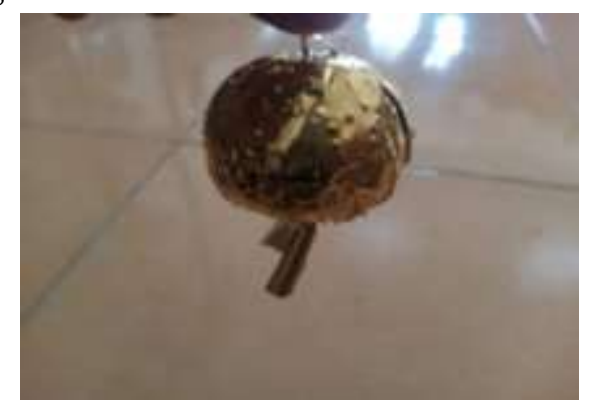

Gambar 13. Buah Manggus 
Buah manggus merupakan perhiasan yang di pakai pada bagian jari. Buah manggus ini berbentuk bulat seperti buah manggis yang menggantung di bagian jari pengantin wanita. Konsep matematika yang terdapat pada buah manggus adalah bangun ruang yang berbentuk bola atau lingkaran.

e) Bulu serati

Bulu serati adalah nama ikat pinggang yang di pakai oleh pengantin wanita maupun pria Lampung. Di pakai tepat di ikatkan di pinggang .

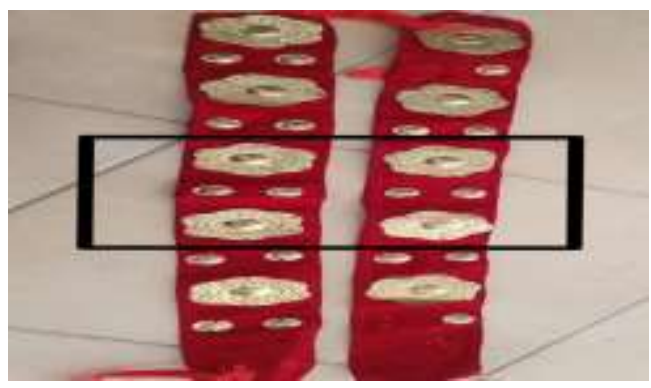

Gambar 14. Bulu Serati

Konsep matematika yang terkandung dalam ikat pinggang bulu serati ini berupa bangun datar (pesegi panjang, lingkaran) dan bilangan yaitu terdapat 5 hiasan motif bunga pada ikat pinggang serati.

\section{SIMPULAN}

Berdasarkan hasil kajian dan eksplorasi terhadap konsep matematika diperoleh bahwa pakaian adat Lampung mengandung konsep matematika antara lain bentuk geometri, konsep bilangan, sudut dan transformasi geometri.

\section{REFERENCES}

Avelia, L. T., Nugraheni, F. A., \& Palma, D. I. (2020). Etnomatematika pada Kain Tapis Lampung Motif Pucuk Rebung. Seminar Nasional Pendidikan Matematika, 1(1), 373-382. https://conference.unikal.ac.id/index.php/sandika/sandika1/paper/view/430

Hartoyo. (2012). Eksporasi Etnomatematika Pada Budaya Masyarakat Dayak Perbatasan Indonesia dan Malasia. 13(1), 14-23.

Loviana, S., Merliza, P., Damayanti, A., Mahfud, M. K., \& Islamuddin, A. M. (2020). Etnomatematika pada Kain Tapis dan Rumah Adat Lampung. Tapis : Jurnal Penelitian Ilmiah, 4(1), 94-110. https://doi.org/10.32332/tapis.v4i1.1956

Merliza, P. (2021). Studi Etnomatematika : Eksplorasi Konsep Matematika pada Permainan Tradisional Provinsi Lampung. Suska Journal of Mathematics Education, 71), 21-30. http://ejournal.uinsuska.ac.id/index.php/SJME/article/view/12537/6377

Musafiri, M. R. Al. (2016). Peran Krearifan Lokal Bagi Pengembangan Pendidikan Karakter Pada Sekolah Menengah Atas. 1, 1-19. 
Sulfemi, W. B. (2019). Manajemen Pendidikan Berbasis Multi Budaya. INA-Rxiv Pappers. https://doi.org/10.31227/osf.io/647wy

Wahyuni, A., \& Aji. (2013). Peran Etnomatematika dalam Membangun Karakter Bangsa. November, 113-118. 